This item was submitted to Loughborough's Research Repository by the author.

Items in Figshare are protected by copyright, with all rights reserved, unless otherwise indicated.

\title{
Studying coopetition in a wine industry context: Directions for future research
}

PLEASE CITE THE PUBLISHED VERSION

https://doi.org/10.1108/IJWBR-11-2017-0067

PUBLISHER

(C) Emerald

VERSION

AM (Accepted Manuscript)

\section{PUBLISHER STATEMENT}

This work is made available according to the conditions of the Creative Commons Attribution-NonCommercialNoDerivatives 4.0 International (CC BY-NC-ND 4.0) licence. Full details of this licence are available at: https://creativecommons.org/licenses/by-nc-nd/4.0/

\section{LICENCE}

CC BY-NC-ND 4.0

\section{REPOSITORY RECORD}

Crick, James M.. 2019. "Studying Coopetition in a Wine Industry Context: Directions for Future Research". figshare. https://hdl.handle.net/2134/27773. 


\title{
STUDYING COOPETITION IN A WINE INDUSTRY CONTEXT: DIRECTIONS FOR FUTURE RESEARCH
}

\begin{abstract}
Purpose - The purpose of this paper is to highlight the theoretical and methodological value of studying coopetition (the interplay between cooperation and competition) in a wine industry context.

Design/methodology/approach - Key publications surrounding wine industries across multiple countries were reviewed to understand how the wine industry is a highly-appropriate empirical context to investigate coopetition.

Findings - The findings revealed that the wine industry is a highly-suitable empirical context for researchers to explore coopetition. Specifically, being a highly-cooperative and competitive market, the wine industry provides a unique outlook into how coopetition is managed.

Originality/value - This paper helps scholars appreciate the theoretical and methodological benefits of using a wine industry context to evaluate coopetition. Hence, scholars should utilise the wine industry, to obtain rich empirical data surrounding coopetition. The paper ends with a set of recommendations for future research.
\end{abstract}

Key words - Coopetition, wine industry, empirical management research.

Classification - Viewpoint.

\section{Introduction}

The wine industry has been a popular empirical context across the broader management literature, with scholars using this setting to study a range of theoretical issues. In the International Journal of Wine Business Research, studies have examined numerous scholarly and practical issues across multiple countries, finding that the wine industry is an interesting context for empirical management research (e.g., Taplin, 2010; Bamberry and Wickramasekara, 2012). Moreover, the wine industry has also been used as an empirical context used to study the notion of "coopetition", i.e., the interplay between cooperation and competition (reference withheld). Coopetition is defined as "a dynamic and paradoxical relationship, which arises when two companies cooperate in some areas, such as strategic alliances, but simultaneously compete in other areas" (Bengtsson and Kock, 2000, p. 411). According to Crick (2018), the wine industry (specifically, that in New Zealand) is an effective 
empirical context to examine coopetition activities, due to it being a highly-competitive and cooperative market.

The context that researchers use to build or test a certain theory is integral, as has the potential to shape the direction of future research, and yield counter-intuitive findings. If researchers choose the wrong empirical context, it is argued that they are setting themselves up for failure, in which they are likely to obtain non-informative results, and may shape a strand of literature in the wrong direction. As coopetition and other collaborative strategies have been explored in wine industries across the world (Telfer, 2001; Crick, 2018), this article investigates how and why the wine sector is unique for studying coopetition. Therefore, the objective of this paper is to highlight the theoretical and methodological value (for future research) of investigating coopetition in a wine industry context, as well as to outline the under-researched areas in the coopetition literature. This paper helps academics whom follow the developments in the International Journal of Wine Business Research to understand how the wine industry can be used to shape management theory, as well as make contextual contributions.

That is, this paper also seeks to make a set of recommendations to help scholars utilise such an empirical context. It is anticipated that this paper can be used to encourage academics to use the wine industry (across multiple countries) to explore coopetition, to obtain rich empirical data. This viewpoint is also proposed to help wine-makers (i.e., practitioners) to appreciate how coopetition is likely to improve their performance, and how such activities can be managed. As such, this article is divided into the following four sections. First, coopetition is conceptualised, in terms of its facets, antecedents, and consequences (and the gaps in the literature). Second, the empirical context of the wine industry is described, to highlight the themes that the prior literature has uncovered (i.e., not just studies pertaining to coopetition). Third, the cooperativeness and competitiveness of the wine industry is discussed, to highlight why coopetition is an appropriately studied topic in a wine industry context. Fourth, the paper 
ends with a set of conclusions, as well as some recommendations for moving the coopetition literature forward.

\section{The facets, antecedents, and consequences of coopetition}

Coopetition is an activity, in which organisations (or more specifically, managers) collaborate with their competitors, in terms of the sharing of resources (e.g., equipment and hardware) and/or capabilities (e.g., knowledge and experience) (Bengtsson and Kock, 2000). As such, coopetition is a business strategy used to improve company performance (e.g., sales) in ways that would be considerably more difficult if managers did not have access to competitors' resources and/or capabilities. Further, coopetition-oriented behaviours allow organisations to access opportunities (e.g., new markets) that would be unobtainable, if some firms competed on an individualistic-level (Telfer, 2001). Despite coopetition being a well-studied area, there are nevertheless some key research gaps. Specifically, there is scarce research surrounding the antecedents of coopetition activities (please see Figure 1). Thus, there is ample scope to develop the coopetition literature, by uncovering the drivers of coopetition activities (e.g., corporate cultures, and organisational capabilities), to build upon the few studies that have explored such themes (e.g., Crick, 2018). This is important for managers, as it is currently difficult to recommend to practitioners what assets are needed to engage in coopetition. In this current paper, the benefits of using the wine industry to better understand the under-researched area of the antecedents of coopetition-oriented behaviours are explained. The empirical contexts used in wine business research are expanded upon in the following section.

[Insert Figure 1 about here]

\section{Wine business research and empirical contexts}

The global wine industry is divided into two over-arching groups: Old World countries (i.e., established wine markets, such as: France, Italy, and Spain), and New World countries (i.e., 
newer entrants to the wine sector, such as: Australia, South Africa, and New Zealand) (Crick and Crick, 2015). Furthermore, some studies have studied specific regions of certain wineproducing countries; for example, Telfer (2001) explored the strategic alliances of vineyards and wineries in Canada's Niagara region, finding that cooperation with vertical (e.g., supply chain partners) and horizontal (e.g., competitors) partners can improve firms' wine tourism offerings. The wine industry provides scholars with an empirical context to study certain phenomena, with such a setting allowing researchers to build and/or test broader management theories (Bamberry and Wickramasekara, 2012).

Furthermore, Crick (2018) utilised the "New Zealand Winegrowers' database", and identified a sub-set of this population to interview, observe, and indeed contact due to having access to such archival information. Thus, by being able to access organisations (namely, vineyards and wineries), the wine sector allows management researchers to identify participants (e.g., interviewees) to examine a theoretical issue, in which they are investigating. That said, it is acknowledged that other industries have sampling frames to identify firms, but the wine industry nevertheless has been known to help scholars identify and sample companies using various methodologies (Crick and Crick, 2015). The interplay between cooperation and competition in the wine industry is expanded upon in the following section, with respect of the value of studying coopetition in a wine industry context.

\section{The interplay between cooperation and competition in the wine industry}

Wine industries across the world (i.e., in both Old World and New World wine markets) have been found to be highly-cooperative and competitive. Regarding the degree of cooperativeness in the wine industry, as mentioned earlier, Telfer (2001) explored how strategies alliances have played vital (i.e., performance-driving) roles for vineyards and wineries in the Niagara wine region. That is, Telfer (2001) considered vertical and horizontal networks (i.e., where managers 
have collaborative links with suppliers, and competitors), and the performance consequences of such activities (e.g., through wine tourism). Cooperation in the wine industry has also been studied at the functional-level, through value co-creation strategies, whereby, employees (such as those working in cellar doors) cooperate with their customers, to create a value-added experience through wine tourism (reference withheld). In addition to cooperation helping mitigate the chances of vineyards and wineries becoming rogue (i.e., producing poor-quality wine), it allows small firms to survive in their market, by having access to resources and/or capabilities that could be inaccessible or unaffordable, if owner-managers were to compete on an individualistic basis (Crick, 2018).

Moreover, Crick (2018) argued that in rural wine clusters in New Zealand, coopetition can improve, or indeed, destroy such regions (i.e., if not undertaken properly). Specifically, if a bottle of New Zealand wine is purchased in an export market (e.g., the United States or United Kingdom), whilst the producer/seller of the wine directly benefits (i.e., through sales revenues), it can boost the reputation of the region (and country), and therefore, promote the competitors of such a wine brand. Further, regional and national reputations are dependent on customers being satisfied with their wine purchase, as if the customer is satisfied, vineyards and wineries are likely to benefit (due to an association of high-quality wine). However, if customers are not satisfied with their purchase, such organisations' reputations and brands could be tarnished through negative word-of-mouth. Coopetition can help vineyards and wineries boost customers' experiences (and satisfaction) by cooperating through the sharing of resources and/or capabilities to improve the quality of a region's output (and/or wine tourism activities) (Telfer, 2001). Coopetition can also prevent certain competitors from destroying the region's (and country's) reputation by going rogue (Taplin, 2010).

That said, it must be emphasised that the wine industry is also a highly-competitive market. As such, whilst cooperation (across various levels) may indeed occur, vineyards and wineries are 
also in strong competition. Crick and Crick (2015) described that in the New Zealand wine industry, the domestic market is in a state of over-supply, in which the domestic demand for wine is significantly less than the supply of grapes. That is, Crick and Crick (2015) found that the owner-managers of New Zealand vineyards and wineries have adopted various types of innovative business strategies to differentiate their business models from those of competitors (e.g., through internationalisation, and collaborating with vertical channel partners). Whilst coopetition (i.e., in a behavioural form) is the interplay between cooperation and competition (Bengtsson and Kock, 2000), it is rather uncommon for broader management scholars to find empirical contexts that have high-degrees of cooperation and competition. Thus, if academics can discover an empirical context where the forces of cooperation and competition exist, it is recommended that they should utilise such a business environment to investigate how such forces intersect.

Furthermore, wine industries across the world have been found to be highly-cooperative and competitive, whereby, the owner-managers of vineyards and wineries (as well as the other members of the management teams, and their employees) have strong relationships with their competitors (see Taplin, 2010). As noted earlier, Crick (2018) (among other studies) attributed the high-degree of coopetition in the New Zealand wine industry to the need to improve regional (and national) reputations, and to ensure that individual vineyards and wineries do not become rogue producers, and destroy such reputations. However, another issue that makes the wine industry an interesting empirical context to study coopetition, is that such collaborative business strategies apply to several activities. That is, whilst coopetition can assist vineyards and wineries to obtain resources and/or capabilities (that would be difficult in an individualistic business model), coopetition also helps firms improve their wine tourism offerings (Telfer, 2001). Specifically, by having an awareness of competitors' activities, Cellar Door Managers 
have been found to recommend rivals' products and services to customers to deliver a stronger value provision (reference withheld).

Again, this is a phenomenon that is uncommon in other industry contexts, making the wine industry a rich setting to explore the interplay between cooperation and competition, i.e., the multiple forms of coopetition activities. Despite the wine industry (as an empirical context) helping make such contributions to the coopetition literature, there are still certain research gaps. That is, there has been an underlying focus on the dimensions and performance outcomes of coopetition-oriented behaviours (e.g., sales) (Bengtsson and Kock, 2000; Crick, 2018), and a scarce volume of research surrounding the antecedents of coopetition activities. Academics interested in improving the coopetition literature, are strongly-recommended to develop such theory, by studying the antecedents of coopetition-oriented behaviours, to shape scholarly and practical recommendations on what factors motivate companies (or more specifically, managers) to cooperate with their competitors. It is suggested that academics should utilise the wine industry to uncover new evidence about what factors drive organisations to engage in coopetition activities (as well as other research gaps that scholars deem as being important). The directions for future research relating to coopetition in the wine industry follow in the next section.

\section{Directions for future research}

As described in the prior section, wine industries throughout the world have been found to be highly-cooperative and competitive. To stress an earlier point, it is rather uncommon for broader management scholars to find sectors with high-degrees of cooperativeness and competitiveness; thus, when studying coopetition (i.e., the interplay between cooperation and competition), scholars should therefore, take advantage of the wine industry as an empirical context. As there are some research gaps pertaining to the coopetition literature, such as the 
lack of research surrounding the antecedents of coopetition (see Crick, 2018), the wine industry is a highly-suitable empirical context for such work. Henceforth, it is recommended that future studies should not only explore coopetition (particularly, its antecedents), but should use the wine industry as an empirical context to develop such theory.

The wine industry should be used by broader management scholars to better understand how coopetition can be managed in business strategies, to learn as much as possible from this empirical context (including the drivers, and performance outcomes of coopetition). Future research should also examine multiple wine industries to explore coopetition. Moreover, crossnational comparisons between Old World and New World wine-producing countries would also be interesting, to determine if more established wine markets engage in different forms of coopetition to more recent entrants. However, it is advised that academics should begin with comparing culturally and/or economically-similar countries (e.g., a study comparing France and the United States), so that any differences discovered are not through extraneous factors. This paper is concluded in the next section.

\section{Conclusions}

The objective of this study was to outline the theoretical and methodological benefits of using a wine industry context (for empirical research) to study coopetition. This research objective was achieved through conducting a review of key publications surrounding wine industries across multiple countries. As such, the three conclusions from this paper are as follows. First, it is concluded that the wine industry is a unique business environment (and thus, empirical context) for broader management researchers, as high-degrees of cooperation and competition exist - something that it is rare for most industries. Second, it is also concluded that due to the cooperative and competitive nature of the wine industry, researchers should utilise such an empirical context to study some of the research gaps pertaining to the coopetition literature 
(e.g., the antecedents of coopetition). Third, it is concluded that the dimensions and organisational performance outcomes (e.g., sales) of coopetition-oriented behaviours have been well-studied, but there is a need for research surrounding the antecedents of coopetition activities (to help scholars and practitioners understand the best ways to manage such business strategies). In closing, the wine industry is proposed to be an empirical context used to develop the coopetition literature (and study the various research gaps associated with the topic). 


\section{References}

Bamberry, G.B. and Wickramasekara, R. (2012), "Domestic and international strategies in the Queensland wine industry”, International Journal of Wine Business Research, Vol. 24 No. 4, pp. 302-318.

Bengtsson, M. and Kock, S. (2000), "Coopetition in business networks: to cooperate and compete simultaneously”, Industrial Marketing Management, Vol. 29 No. 5, pp. 411-426.

Crick, D. and Crick, J.M. (2015), "Learning and decision-making in marketing planning: a study of New Zealand vineyards", Marketing Intelligence \& Planning, Vol. 33 No. 5, pp. 707732 .

Crick, J.M. (2018), “The facets, antecedents and consequences of coopetition: an entrepreneurial marketing perspective", Qualitative Market Research: An International Journal (Forthcoming).

Taplin, I.M. (2010), "From cooperation to competition: market transformation among elite Napa Valley wine producers", International Journal of Wine Business Research, Vol. 22 No. 1, pp. 6-26.

Telfer, D.J. (2001), "Strategic alliances along the Niagara wine route", Tourism Management, Vol. 22 No. 1, pp. 21-30. 
Figure 1. The state of knowledge in the coopetition literature

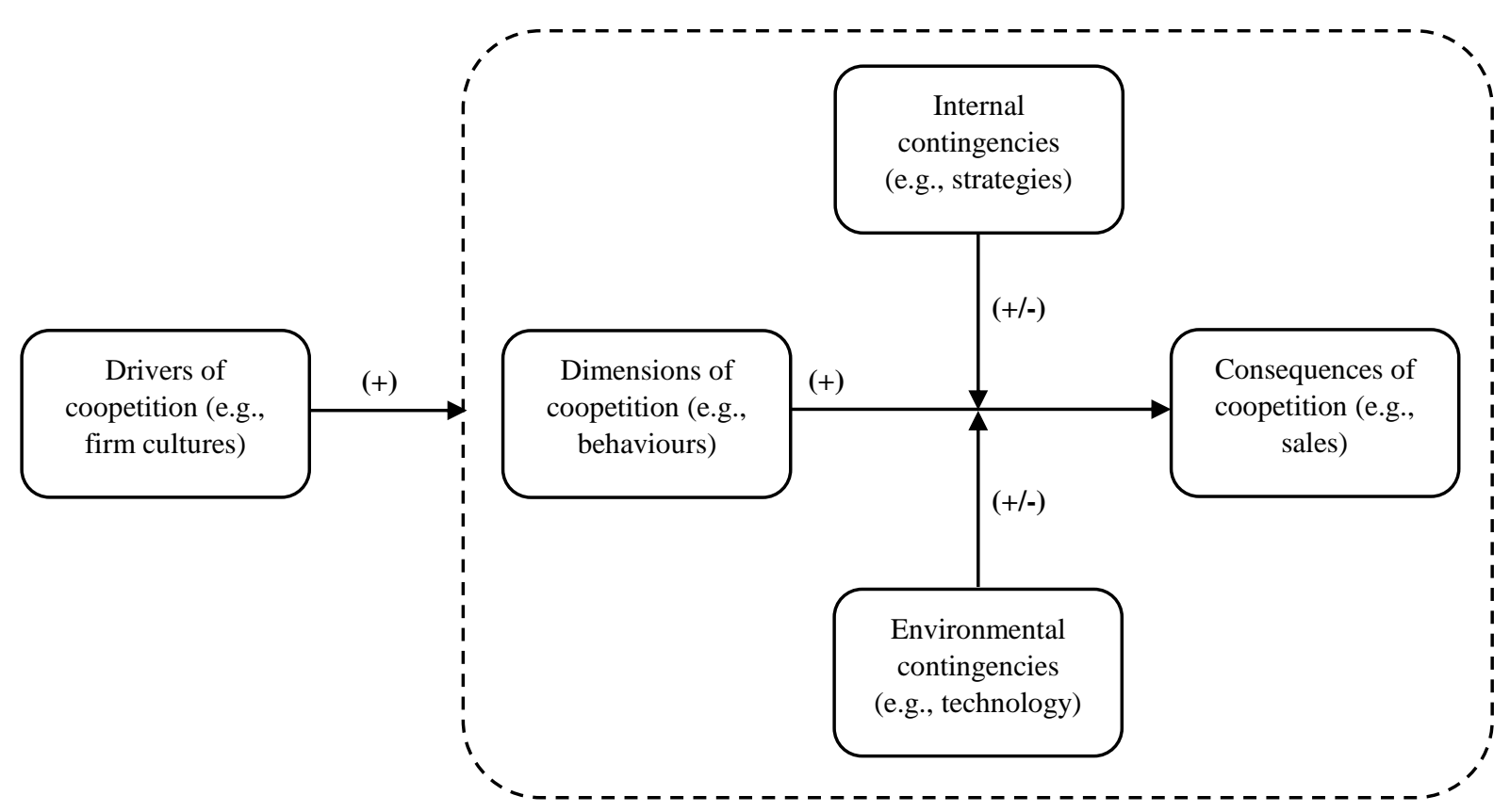

Please note that the components of the framework that are surrounded by dotted lines, represent well-studied areas. That is, the dimensions and performance outcomes of coopetition fall under a rich body of literature. However, there is scarce research surrounding the drivers (or antecedents) of coopetition. 